\title{
Diabetes during pregnancy and perinatal outcomes among First Nations women in Ontario, 2002/03-2014/15: a population-based cohort study
}

\author{
Maria P. Vélez MD PhD, Morgan Slater PhD, Rebecca Griffiths MSc, Baiju R. Shah MD PhD, \\ Roseanne Sutherland, Carmen Jones BA, Kristen Jacklin PhD, Jennifer D. Walker PhD, \\ Michael E. Green MD MPH
}

See related article at www.cmajopen.ca/lookup/doi/10.9778/cmajo.20190096

\section{Abstract}

Background: In Canada, increasing numbers of women, especially First Nations women, are affected by diabetes during pregnancy, which is a major risk factor for adverse maternal and neonatal outcomes. The aim of this study was to examine temporal trends in pregnancy outcomes and use of health care services in a population-based cohort of First Nations women compared to other women in Ontario according to diabetes status during pregnancy.

Methods: Using health administrative databases, we created annual cohorts of pregnant women from 2002/03 to 2014/15 and identified those with preexisting diabetes and gestational diabetes. We used the Indian Register to identify First Nations women. We estimated rates of adverse maternal and infant outcomes, and measures of use of health care services in each population.

Results: There were 1671337 deliveries among 1065950 women during the study period; of these deliveries, 31417 (1.9\%) were in First Nations women, and 1639920 (98.1\%) were in other women. First Nations women had a higher prevalence of preexisting diabetes and gestational diabetes than other women in Ontario. First Nations women with preexisting diabetes had higher rates of preeclampsia (3.2\%-5.6\%), labour induction (33.4\%-42.9\%) and cesarean delivery $(47.8 \%-53.7 \%)$ than other women in Ontario, as did First Nations women with gestational diabetes $(3.2 \%-4.7 \%, 38.5 \%-46.9 \%$ and $41.4 \%-43.4 \%$, respectively). The rate of preterm birth was similar between First Nations women and other women in Ontario. Although First Nations women had a higher rate of babies who were large for gestational age than other women, regardless of diabetes status, obstructed labour rates were similar for the 2 cohorts. Almost all First Nations women, regardless of diabetes status, were seen by a primary care provider during their pregnancy, but rates of use of specialty care were lower for First Nations women than for other women. Fifteen percent of all pregnant women with preexisting diabetes visited an ophthalmologist during their pregnancy.

Interpretation: Our results confirm disparities in maternal and neonatal outcomes between First Nations women and other women in Ontario. Access to primary care for pregnant women seemed adequate, but access to specialized care, especially for women with preexisting diabetes, needs to improve.

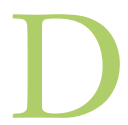
iabetes mellitus during pregnancy, either preexisting diabetes or gestational diabetes, is a major contributor of adverse outcomes. In Canada, the number of women affected by diabetes during pregnancy has increased over time ${ }^{1,2}$ and the risk is higher in First Nations women. ${ }^{3-6}$ Although Ontario is home to the largest group of First Nations people in Canada (23.6\%), little is known about the health care experience of pregnant First Nations women in the province.

There are complex social and historical factors that affect the lived experience of First Nations women. ${ }^{8-11}$ It is also important to acknowledge the resilience of First Nations women and communities to improve their health outcomes. ${ }^{12}$ Qualitative research in First Nations women highlights the

Competing interests: None declared.

This article has been peer reviewed.

Correspondence to: Maria Vélez, maria.velez@queensu.ca CMAJ Open 2020. DOI:10.9778/cmajo.20190195 
need to improve pregnancy care through a more patientcentred-care approach. ${ }^{13}$ In this context, surveillance of diabetes during pregnancy is important for quantifying whether disparities in pregnancy outcomes have decreased between First Nations women and other populations.

The aim of the present study was to examine temporal trends in pregnancy outcomes and use of health care services in a population-based cohort of First Nations women compared to other women in Ontario according to diabetes status during pregnancy.

\section{Methods}

\section{Setting and design}

This was a population-based cohort study of all hospital deliveries among women 13-50 years old in Ontario from Apr. 1, 2002, to Mar. 31, 2015 using health data sets housed by ICES. This work is part of a larger, collaborative project between the Chiefs of Ontario and academic researchers to describe the landscape of diabetes in First Nations people in Ontario. ${ }^{14,15}$

\section{Study population and data sources}

The creation of the cohorts and description of the major data sets used are described elsewhere. ${ }^{16} \mathrm{We}$ identified women and their newborns through the MOMBABY data set, ${ }^{17}$ which includes records derived from the Discharge Abstract Database for all mother-newborn pairs in which the baby was delivered from 2002/03 onward and captures 99\% of all births in Ontario. ${ }^{18}$ Only singleton pregnancies were included. We identified First Nations women using the Indian Register, which includes people who are recognized and registered as First Nations people by the federal government under the Indian Act. ${ }^{19,20}$

\section{Study exposures}

We used the Ontario Diabetes Database to identify women with preexisting diabetes, defined as diagnosis of diabetes (type 1 or type 2 ) at any point before pregnancy. We defined gestational diabetes according to Booth and colleagues ${ }^{18}$ definition (for which they used a validated algorithm): the presence of 1 or more diagnostic codes of diabetes from hospital discharge abstract records, or 2 or more billing claims with diagnosis of diabetes in the last 120 days of pregnancy, in the absence of preexisting diabetes.

\section{Outcomes}

We compared the prevalence of preexisting diabetes and gestational diabetes in First Nations women versus other women in Ontario. To estimate rates of common maternal and infant indicators of perinatal surveillance, ${ }^{21}$ we linked data for women and their newborns using the Discharge Abstract Database. Maternal outcomes included preeclampsia, induction of labour, obstructed labour and cesarean delivery. Infant outcomes included preterm birth $(<37 \mathrm{wk}$ in gestational age), large for gestational age (birth weight $>90$ th percentile for gestational age according to Canadian growth

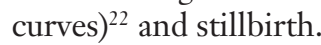

We determined use of health care services during pregnancy, including visits to primary care, obstetrics and gynecology, internal medicine or endocrinology (for women with gestational diabetes or preexisting diabetes), and ophthalmology or optometry (for women with preexisting diabetes), by examining physician billing claims for the period up to 280 days before delivery.

\section{Statistical analysis}

Maternal age was captured at time of delivery. Each delivery was counted separately. Estimates of prevalence and maternal and infant outcomes were age-standardized to 2002/03. We estimated the prevalence (per 1000 deliveries) of preexisting diabetes and gestational diabetes in the 2 cohorts yearly from 2002/03 to 2014/15. We expressed the frequency of maternal and neonatal outcomes and their $95 \%$ confidence intervals (CIs) in women with no diabetes, preexisting diabetes and gestational diabetes using rates (per 100 deliveries) for 3 periods: 2002/03 to 2004/05, $2006 / 07$ to $2009 / 10$, and $2010 / 11$ to $2014 / 15$. We used age-standardized incidence rate ratios (IRRs) and $95 \%$ CIs to contrast rates for the 3 periods between First Nations women and other women in Ontario. We used the direct standardization method and the Mantel-Haenszel rate ratio statistic to compare ratios. We used the CochranArmitage trend test to assess temporal trends from 2002/03 to $2014 / 15$. Privacy considerations necessitated the suppression of cells with small values $(\leq 5)$. All analyses were carried out with SAS Enterprise Guide version 7.1 (SAS Institute).

\section{Ethics approval}

The project received approval from the Chiefs of Ontario Data Governance Committee and the research ethics boards of Queen's University and Laurentian University.

\section{Resullts}

We identified 1671337 deliveries among 1065950 women between 2002/03 and 2014/15 in Ontario. Of these deliveries, 31417 (1.9\%) were in First Nations women, and 1639920 $(98.1 \%)$ were in other women. The mean age at delivery was 25.2 (standard deviation 5.9) years for First Nations women and 30.1 (standard deviation 5.5) years among other women.

The prevalence of both preexisting diabetes and gestational diabetes was higher among First Nations women than other women in each of the years studied (Figure 1; Appendix 1, available at www.cmajopen.ca/content/8/1/E214/ suppl/DC1). For example, the prevalence per 1000 deliveries was 52.3 versus 13.9 in $2002 / 03$ and 40.7 versus 20.5 in $2014 / 15$ for preexisting diabetes, and 80.8 versus 36.6 in $2002 / 03$ and 108.9 versus 60.7 in 2014/15 for gestational diabetes.

During the study period, the rate of gestational diabetes per 1000 deliveries increased among all women (80.8 to 108.9 in First Nations women $[p=0.003]$ and 36.6 to 60.7 in other women $[p<0.001])$. The rate of preexisting diabetes per 


\section{Research}

A

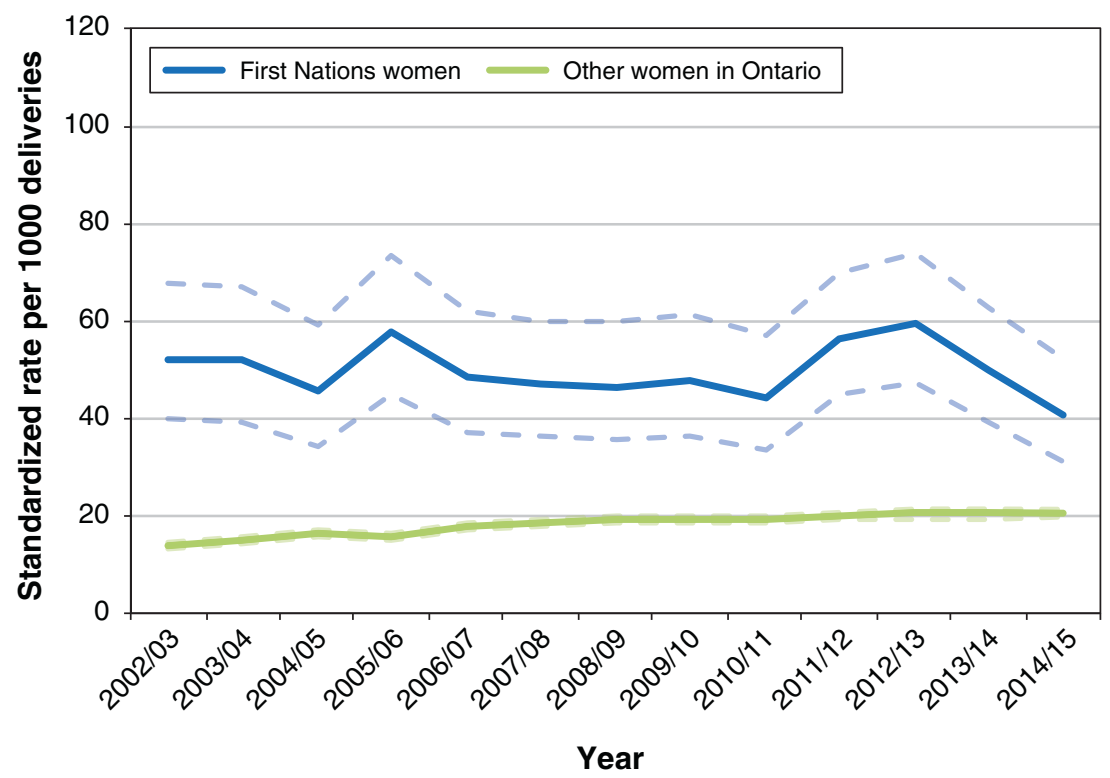

B

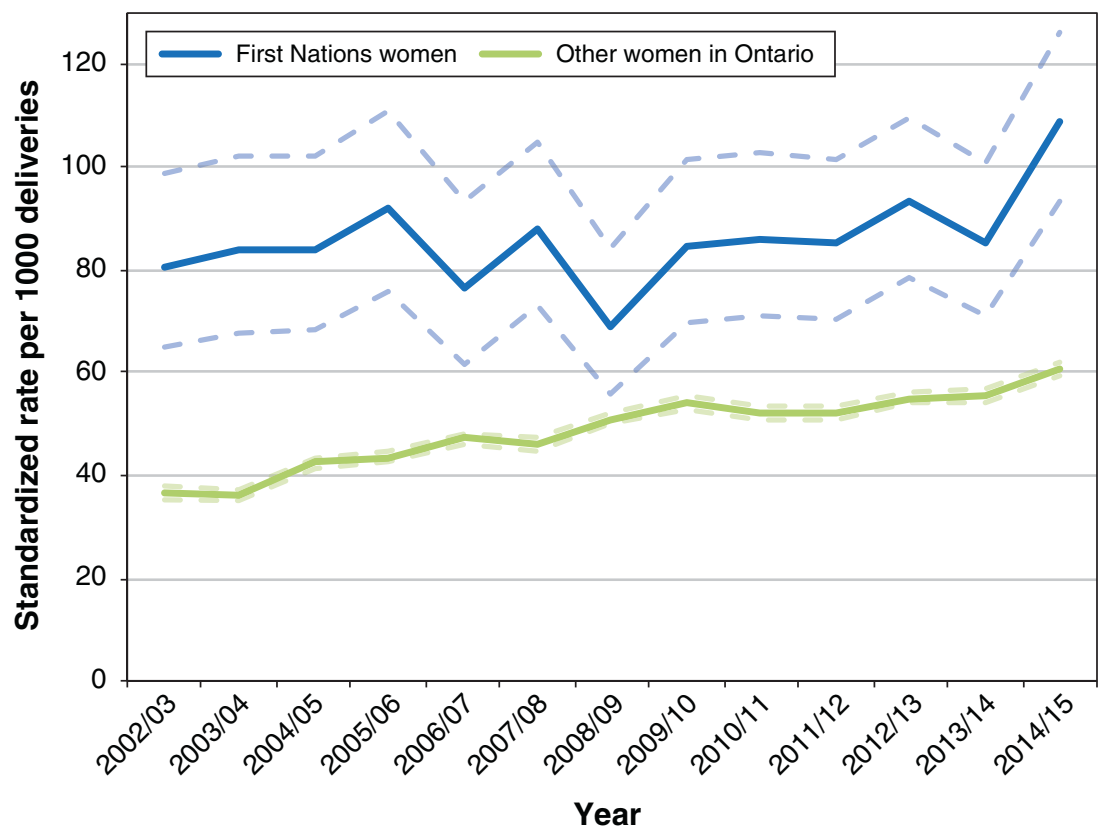

Figure 1: Temporal trends in preexisting diabetes $(A)$ and gestational diabetes $(B)$ during pregnancy among First Nations women and other women in Ontario, 2002/03 to 2014/15. Dotted lines represent 95\% confidence intervals.

1000 deliveries increased among other women (13.9 to 20.5 $[p<0.001])$ but did not follow a linear trend in First Nations women, increasing from 52.3 in $2002 / 03$ to 59.5 in $2012 / 13$, then decreasing to 40.5 in $2014 / 15(p=0.6)$.

\section{Maternal outcomes}

Maternal outcomes are shown in Tables 1A-1C. First Nations women had higher rates of preeclampsia than other women regardless of diabetes status. Among those with 


\begin{tabular}{|c|c|c|c|c|c|c|}
\hline \multirow[b]{2}{*}{ Outcome } & \multicolumn{3}{|c|}{ Other women } & \multicolumn{3}{|c|}{ First Nations women } \\
\hline & $\begin{array}{l}2002 / 03- \\
2005 / 06\end{array}$ & $\begin{array}{l}2006 / 07- \\
2009 / 10\end{array}$ & $\begin{array}{l}2010 / 11- \\
2014 / 15\end{array}$ & $\begin{array}{l}2002 / 03- \\
2005 / 06\end{array}$ & $\begin{array}{l}2006 / 07- \\
2009 / 10\end{array}$ & $\begin{array}{l}2010 / 11- \\
2014 / 15\end{array}$ \\
\hline \multicolumn{7}{|l|}{ Preeclampsia } \\
\hline $\begin{array}{l}\text { Rate per } 100 \text { deliveries } \\
(95 \% \mathrm{Cl})\end{array}$ & $1.1(1.1-1.1)$ & $1.0(1.0-1.1)$ & $1.3(1.2-1.3)$ & $1.4(1.1-1.8)$ & $1.3(1.0-1.7)$ & $1.7(1.4-2.1)$ \\
\hline $\operatorname{IRR}(95 \% \mathrm{CI})$ & & & & $1.32(1.04-1.66)$ & $1.29(1.01-1.65)$ & $1.36(1.13-1.63)$ \\
\hline $\begin{array}{l}p \text { for trend 2002/03- } \\
2014 / 15\end{array}$ & & $<0.001$ & & & 0.2 & \\
\hline \multicolumn{7}{|l|}{ Labour induction } \\
\hline $\begin{array}{l}\text { Rate per } 100 \text { deliveries } \\
(95 \% \mathrm{Cl})\end{array}$ & $20.6(20.5-20.7)$ & $20.8(20.6-20.9)$ & $24.1(23.9-24.2)$ & $22.5(21.1-23.9)$ & $23.7(22.4-25.0)$ & $26.4(25.2-27.7)$ \\
\hline IRR $(95 \% \mathrm{Cl})$ & & & & $1.09(1.03-1.16)$ & $1.14(1.08-1.21)$ & $1.10(1.05-1.15)$ \\
\hline $\begin{array}{l}p \text { for trend 2002/03- } \\
2014 / 15\end{array}$ & & $<0.001$ & & & $<0.001$ & \\
\hline \multicolumn{7}{|l|}{ Obstructed labour } \\
\hline $\begin{array}{l}\text { Rate per } 100 \text { deliveries } \\
(95 \% \mathrm{Cl})\end{array}$ & $5.7(5.6-5.7)$ & $6.2(6.1-6.3)$ & $6.2(6.1-6.3)$ & $4.6(4.0-5.3)$ & $5.5(4.9-6.2)$ & $5.3(4.8-5.9)$ \\
\hline IRR $(95 \% \mathrm{Cl})$ & & & & $0.81(0.71-0.93)$ & $0.89(0.79-1.00)$ & $0.86(0.78-0.95)$ \\
\hline $\begin{array}{l}p \text { for trend 2002/03- } \\
2014 / 15\end{array}$ & & $<0.001$ & & & 0.03 & \\
\hline \multicolumn{7}{|l|}{ Cesarean delivery } \\
\hline $\begin{array}{l}\text { Rate per } 100 \text { deliveries } \\
(95 \% \mathrm{Cl})\end{array}$ & $26.5(26.4-26.7)$ & $28.3(28.2-28.5)$ & 27.8 (27.7-27.9) & $27.4(25.8-29.0)$ & $28.9(27.4-30.4)$ & $28.5(27.2-29.8)$ \\
\hline IRR $(95 \% \mathrm{Cl})$ & & & & $1.03(0.98-1.10)$ & $1.02(0.97-1.07)$ & $1.02(0.98-1.07)$ \\
\hline $\begin{array}{l}p \text { for trend 2002/03- } \\
2014 / 15\end{array}$ & & $<0.001$ & & & 0.009 & \\
\hline
\end{tabular}

preexisting diabetes, First Nations women had 1.80 times (95\% CI 1.07-3.03) the rate of preeclampsia as other women in 2002/03-2005/06. First Nations women with gestational diabetes had 1.66 times (95\% CI 1.00-2.77) the rate of preeclampsia as other women with gestational diabetes in 2002/03-2005/06 and 2.09 times (95\% CI 1.49-2.93) the rate in $2010 / 11-2014 / 15$.

Rates of labour induction were higher in First Nations women than other women regardless of diabetes status. Among those with preexisting diabetes, First Nations women had 1.17 times (95\% CI $1.00-1.43$ ) the rate of labour induction as other women in 2002/03-2005/06 and 1.22 times (95\% CI 1.05-1.43) the rate in 2010/11-2014/15. First Nations women with gestational diabetes had 1.28 times (95\% CI 1.11-1.49) the rate of labour induction as other women with gestational diabetes in 2002/03-
2005/06 and 1.25 times (95\% CI $1.13-1.38$ ) the rate in 2010/11-2014/15.

Rates of obstructed labour were similar between First Nations women and other women with diabetes. Among those with preexisting diabetes, First Nations women had 1.26 times (95\% CI $1.07-1.48$ ) the rate of cesarean delivery as other women in 2002/03-2005/06 and 1.22 times (95\% CI $1.06-1.40$ ) the rate in 2010/11-2014/15. First Nations women with gestational diabetes had 1.18 times (95\% CI 1.03-1.36) the rate of cesarean delivery as other women with gestational diabetes in 2002/03-2005/06 and 1.19 times (95\% CI 1.071.33 ) the rate in 2010/11-2014/15.

\section{Neonatal outcomes}

Neonatal outcomes are shown in Tables 2A-2C. First Nations women without diabetes and those with preexisting 


\begin{tabular}{|c|c|c|c|c|c|c|}
\hline \multirow[b]{2}{*}{ Outcome } & \multicolumn{3}{|c|}{ Other women } & \multicolumn{3}{|c|}{ First Nations women } \\
\hline & $\begin{array}{c}2002 / 03- \\
2005 / 06\end{array}$ & $\begin{array}{l}2006 / 07- \\
2009 / 10\end{array}$ & $\begin{array}{l}2010 / 11- \\
2014 / 15\end{array}$ & $\begin{array}{l}2002 / 03- \\
2005 / 06\end{array}$ & $\begin{array}{c}2006 / 07- \\
2009 / 10\end{array}$ & $\begin{array}{l}2010 / 11- \\
2014 / 15\end{array}$ \\
\hline \multicolumn{7}{|l|}{ Preeclampsia } \\
\hline $\begin{array}{l}\text { Rate per } 100 \text { deliveries } \\
(95 \% \mathrm{Cl})\end{array}$ & $3.1(2.6-3.7)$ & $2.8(2.4-3.3)$ & $3.7(3.3-4.3)$ & $5.6(3.2-9.1)$ & $4.9(2.7-8.1)$ & $3.2(1.8-5.4)$ \\
\hline IRR (95\% CI) & & & & $1.80(1.07-3.03)$ & $1.73(1.01-2.95)$ & $0.86(0.50-1.48)$ \\
\hline $\begin{array}{l}p \text { for trend } 2002 / 03- \\
2014 / 15\end{array}$ & & $<0.001$ & & & 0.2 & \\
\hline \multicolumn{7}{|l|}{ Labour induction } \\
\hline $\begin{array}{l}\text { Rate per } 100 \text { deliveries } \\
(95 \% \mathrm{Cl})\end{array}$ & $28.6(27.2-30.1)$ & $30.7(29.4-32.0)$ & $35.1(33.8-36.4)$ & $33.4(27.1-40.8)$ & $40.1(33.2-48.0)$ & $42.9(36.7-49.9)$ \\
\hline IRR (95\% CI) & & & & $1.17(1.00-1.43)$ & $1.31(1.08-1.57)$ & $1.22(1.05-1.43)$ \\
\hline $\begin{array}{l}p \text { for trend } 2002 / 03- \\
2014 / 15\end{array}$ & & $<0.001$ & & & 0.048 & \\
\hline \multicolumn{7}{|l|}{ Obstructed labour } \\
\hline $\begin{array}{l}\text { Rate per } 100 \text { deliveries } \\
(95 \% \mathrm{Cl})\end{array}$ & $5.8(5.2-6.4)$ & $6.4(5.8-7.1)$ & $6.3(5.8-6.9)$ & $3.6(1.8-6.4)$ & $6.2(3.7-9.8)$ & $3.7(2.1-6.2)$ \\
\hline $\operatorname{IRR}(95 \% \mathrm{Cl})$ & & & & $0.62(0.34-1.13)$ & $0.97(0.61-1.54)$ & $0.59(0.35-1.00)$ \\
\hline $\begin{array}{l}p \text { for trend } 2002 / 03- \\
2014 / 15\end{array}$ & & 0.5 & & & 0.7 & \\
\hline \multicolumn{7}{|l|}{ Cesarean delivery } \\
\hline $\begin{array}{l}\text { Rate per } 100 \text { deliveries } \\
(95 \% \mathrm{Cl})\end{array}$ & $42.6(41.0-44.3)$ & $44.2(42.7-45.8)$ & $43.6(42.3-45.0)$ & $53.7(45.6-62.9)$ & $47.8(40.2-56.5)$ & $53.1(46.2-60.7)$ \\
\hline $\operatorname{IRR}(95 \% \mathrm{Cl})$ & & & & $1.26(1.07-1.48)$ & $1.08(0.91-1.28)$ & $1.22(1.06-1.40)$ \\
\hline $\begin{array}{l}p \text { for trend } 2002 / 03- \\
2014 / 15\end{array}$ & & 0.01 & & & 0.5 & \\
\hline
\end{tabular}

diabetes had a similar rate of preterm birth as their non-First Nations counterparts. Among those with gestational diabetes, First Nations women had 1.21 times (95\% CI 1.00-1.47) the rate of preterm birth as other women in 2010/11-2014/15.

First Nations women had a higher rate of babies who were large for gestational age than other women regardless of diabetes status. Among those with preexisting diabetes, First Nations women had 2.00 times (95\% CI 1.67-2.40) the rate of babies who were large for gestational age as other women in 2002/03-2005/06 and 1.90 times (95\% CI 1.63-2.22) the rate in 2010/11-2014/15. First Nations women with gestational diabetes had 3.03 times (95\% CI 2.65-3.48) the rate of babies who were large for gestational age as other women with gestational diabetes in 2002/032005/06 and 3.27 times (95\% CI 2.93-3.66) the rate in 2010/11-2014/15.
First Nations women without diabetes had a similar rate of babies with congenital anomalies as other women without diabetes. Among those with preexisting diabetes, First Nations women had 2.20 times (95\% CI 1.62-2.99) the rate of babies with congenital anomalies as other women in 2002/032005/06 and 1.62 times (95\% CI $1.23-2.13$ ) the rate in 2010/11-2014/15. First Nations women with gestational diabetes had 1.40 times (95\% CI 1.02-1.93) the rate of babies with congenital anomalies as other women with gestational diabetes in 2002/03-2005/06 and 1.34 times (95\% CI 1.041.72) the rate in 2010/11-2014/15.

First Nations women had a higher rate of stillbirth than other women regardless of diabetes status. Among those with preexisting diabetes, First Nations women had 2.19 times (95\% CI 1.09-4.40) the rate of stillbirth as other women in 2002/03-2005/06. First Nations women with 


\begin{tabular}{|c|c|c|c|c|c|c|}
\hline \multirow[b]{2}{*}{ Outcome } & \multicolumn{3}{|c|}{ Other women } & \multicolumn{3}{|c|}{ First Nations women } \\
\hline & $\begin{array}{l}2002 / 03- \\
2005 / 06\end{array}$ & $\begin{array}{l}2006 / 07- \\
2009 / 10\end{array}$ & $\begin{array}{l}2010 / 11- \\
2014 / 15\end{array}$ & $\begin{array}{l}2002 / 03- \\
2005 / 06\end{array}$ & $\begin{array}{l}2006 / 07- \\
2009 / 10\end{array}$ & $\begin{array}{l}2010 / 11- \\
2014 / 15\end{array}$ \\
\hline \multicolumn{7}{|l|}{ Preeclampsia } \\
\hline $\begin{array}{l}\text { Rate per } 100 \text { deliveries } \\
(95 \% \mathrm{Cl})\end{array}$ & $1.9(1.7-2.1)$ & $1.6(1.4-1.8)$ & $2.1(1.9-2.3)$ & $3.2(1.8-5.2)$ & $4.7(3.0-7.1)$ & $4.4(3.1-6.1)$ \\
\hline IRR (95\% CI) & & & & $1.66(1.00-2.77)$ & $2.96(1.93-4.55)$ & 2.09 (1.49-2.93) \\
\hline $\begin{array}{l}p \text { for trend 2002/03- } \\
2014 / 15\end{array}$ & & $<0.001$ & & & 0.2 & \\
\hline \multicolumn{7}{|l|}{ Labour induction } \\
\hline $\begin{array}{l}\text { Rate per } 100 \text { deliveries } \\
(95 \% \mathrm{Cl})\end{array}$ & $30.0(29.1-30.9)$ & 30.7 (29.9-31.5) & $37.5(36.7-38.3)$ & $38.5(33.2-44.4)$ & $42.4(36.9-48.6)$ & $46.9(42.3-51.8)$ \\
\hline $\operatorname{IRR}(95 \% \mathrm{Cl})$ & & & & $1.28(1.11-1.49)$ & $1.38(1.20-1.59)$ & $1.25(1.13-1.38)$ \\
\hline $\begin{array}{l}p \text { for trend 2002/03- } \\
2014 / 15\end{array}$ & & $<0.001$ & & & 0.001 & \\
\hline \multicolumn{7}{|l|}{ Obstructed labour } \\
\hline $\begin{array}{l}\text { Rate per } 100 \text { deliveries } \\
(95 \% \mathrm{Cl})\end{array}$ & $5.8(5.4-6.2)$ & $6.5(6.1-6.8)$ & $6.6(6.2-6.9)$ & $4.6(2.9-6.9)$ & $5.8(3.9-8.3)$ & $5.5(4.1-7.4)$ \\
\hline IRR $(95 \% \mathrm{CI})$ & & & & $0.79(0.52-1.21)$ & $0.90(0.63-1.30)$ & $0.84(0.63-1.13)$ \\
\hline $\begin{array}{l}p \text { for trend 2002/03- } \\
2014 / 15\end{array}$ & & $<0.001$ & & & 0.4 & \\
\hline \multicolumn{7}{|l|}{ Cesarean delivery } \\
\hline $\begin{array}{l}\text { Rate per } 100 \text { deliveries } \\
(95 \% \mathrm{Cl})\end{array}$ & 35.4 (34.5-36.3) & $37.4(36.6-38.2)$ & $36.4(35.7-37.1)$ & $41.8(36.2-48.1)$ & $41.4(36.0-47.4)$ & $43.4(38.9-48.3)$ \\
\hline IRR $(95 \% \mathrm{Cl})$ & & & & $1.18(1.03-1.36)$ & $1.11(0.97-1.27)$ & $1.19(1.07-1.33)$ \\
\hline $\begin{array}{l}p \text { for trend 2002/03- } \\
2014 / 15\end{array}$ & & 0.2 & & & 0.6 & \\
\hline
\end{tabular}

gestational diabetes had 2.64 times (95\% CI 1.20-5.81) the rate of stillbirth as their non-First Nations counterparts in 2010/11-2014/15.

\section{Use of health care services}

Tables 3A-3C present data on the use of health care services. The majority of women, independent of diabetes status, were seen by a primary care provider at least once during their pregnancy, but the rate was lower among First Nations women with preexisting diabetes (IRR 0.97, 95\% CI 0.861.09 in $2002 / 03-2005 / 06$; IRR 0.87 , 95\% CI $0.78-0.97$ in 2010/11-2014/15) and those with gestational diabetes (IRR 0.92, 95\% CI 0.84-1.01 in 2002/03-2005/06; IRR 0.82, 0.760.89 in 2010/11-2014/15) than among their non-First Nations counterparts.

Most women with preexisting diabetes or gestational diabetes had seen an obstetrician/gynecologist, but the rate was lower among First Nations women with preexisting diabetes (IRR $0.82,95 \%$ CI $0.72-0.94$ in 2002/032005/06; IRR 0.84, 0.75-0.94 in 2010/11-2014/15) and those with gestational diabetes (IRR 0.81 , 95\% CI $0.73-$ 0.89 in 2002/03-2005/06; IRR 0.83 , 95\% CI $0.77-0.90$ in 2010/11-2014/15) than among their non-First Nations counterparts.

The rate of consultation with an internal medicine or endocrinology specialist was also lower among First Nations women with preexisting diabetes (IRR 0.70 , 95\% CI 0.58 0.84 in 2002/03-2005/06; IRR 0.82, 95\% CI 0.71-0.94 in 2010/11-2014/15) and those with gestational diabetes (IRR $0.47,95 \%$ CI $0.40-0.55$ in 2002/03-2005/06; IRR 0.51, 95\% CI $0.45-0.57$ in $2010 / 11-2014 / 15)$ than among their nonFirst Nations counterparts.

Only $15 \%$ of women with preexisting diabetes saw an ophthalmologist or optometrist during pregnancy; there 


\begin{tabular}{|c|c|c|c|c|c|c|}
\hline \multirow[b]{2}{*}{ Outcome } & \multicolumn{3}{|c|}{ Other women } & \multicolumn{3}{|c|}{ First Nations women } \\
\hline & 2002/03-2005/06 & $\begin{array}{l}2006 / 07- \\
2009 / 10\end{array}$ & $\begin{array}{l}2010 / 11- \\
2014 / 15\end{array}$ & $\begin{array}{l}2002 / 03- \\
2005 / 06\end{array}$ & $\begin{array}{l}2006 / 07- \\
2009 / 10\end{array}$ & $\begin{array}{l}2010 / 11- \\
2014 / 15\end{array}$ \\
\hline \multicolumn{7}{|l|}{ Preterm delivery } \\
\hline $\begin{array}{l}\text { Rate per } 100 \text { births } \\
(95 \% \mathrm{Cl})\end{array}$ & $7.5(7.4-7.6)$ & $7.8(7.7-7.9)$ & $7.5(7.4-7.6)$ & $7.7(6.9-8.6)$ & $8.5(7.7-9.4)$ & $8.8(8.0-9.5)$ \\
\hline IRR $(95 \% \mathrm{CI})$ & & & & $1.03(0.92-1.14)$ & $1.10(0.99-1.21)$ & $1.17(1.07-1.27)$ \\
\hline $\begin{array}{l}p \text { for trend 2002/03- } \\
2014 / 15\end{array}$ & & 0.9 & & & 0.02 & \\
\hline \multicolumn{7}{|c|}{ Large for gestational age } \\
\hline $\begin{array}{l}\text { Rate per } 100 \text { births } \\
(95 \% \mathrm{Cl})\end{array}$ & $11.0(10.9-11.1)$ & $10.2(10.1-10.3)$ & $9.5(9.4-9.6)$ & $24.2(22.7-25.8)$ & $23.7(22.3-25.1)$ & $21.2(20.0-22.3)$ \\
\hline IRR $(95 \% \mathrm{CI})$ & & & & $2.21(2.08-2.35)$ & $2.31(2.18-2.45)$ & $2.23(2.11-2.36)$ \\
\hline $\begin{array}{l}p \text { for trend } 2002 / 03- \\
2014 / 15\end{array}$ & & $<0.001$ & & & $<0.001$ & \\
\hline \multicolumn{7}{|l|}{ Congenital anomaly } \\
\hline $\begin{array}{l}\text { Rate per } 100 \text { births } \\
(95 \% \mathrm{Cl})\end{array}$ & $5.1(5.0-5.2)$ & $4.8(4.7-4.8)$ & $5.6(5.5-5.6)$ & $5.4(4.7-6.1)$ & $4.7(4.1-5.4)$ & $5.2(4.7-5.8)$ \\
\hline IRR $(95 \% \mathrm{CI})$ & & & & $1.05(0.92-1.19)$ & $0.99(0.87-1.13)$ & $0.94(0.85-1.05)$ \\
\hline $\begin{array}{l}p \text { for trend 2002/03- } \\
2014 / 15\end{array}$ & & $<0.001$ & & & 0.6 & \\
\hline \multicolumn{7}{|l|}{ Stillbirth } \\
\hline $\begin{array}{l}\text { Rate per } 100 \text { births } \\
(95 \% \mathrm{Cl})\end{array}$ & $0.6(0.6-0.7)$ & $0.6(0.5-0.6)$ & $0.5(0.5-0.6)$ & $0.8(0.6-1.2)$ & $0.8(0.6-1.2)$ & $0.9(0.7-1.2)$ \\
\hline IRR $(95 \% \mathrm{CI})$ & & & & $1.34(0.97-1.86)$ & $1.49(1.08-2.05)$ & $1.66(1.28-2.15)$ \\
\hline $\begin{array}{l}p \text { for trend 2002/03- } \\
2014 / 15\end{array}$ & & $<0.001$ & & & 0.8 & \\
\hline
\end{tabular}

was no difference in the rate between First Nations women and other women.

\section{Interpretation}

Our results confirm disparities in maternal and neonatal outcomes between First Nations women and other women in Ontario. Although access to primary care during pregnancy seems adequate, access to specialized care, especially for women with preexisting diabetes, appears inadequate.

Contrary to our findings, Oster and colleagues ${ }^{6}$ reported a lower rate of pregnancy-induced hypertension, including preeclampsia, in First Nations women than other women in Alberta, and no difference between the 2 populations in the rate of gestational diabetes. In addition, those authors did not find higher rates of labour induction or cesarean delivery in First Nations women than in other women. It is important to mention, however, that labour induction and cesarean delivery are interventions to be used optimally. The Society of Obstetricians and Gynaecologists of Canada guideline on diabetes in pregnancy recommends that labour induction be offered between 38 and 40 weeks' gestation in pregnant women with diabetes, depending on other factors, including glycemic control and other comorbidities, ${ }^{23}$ Thus, the higher rates of labour induction and caesarean delivery in First Nations women may be explained by confounding by indication (poorer glycemic control and other comorbidities in First Nations women).

In the present study, First Nations women with diabetes had a similar rate of preterm birth as other women with diabetes. In contrast, Liu and colleagues ${ }^{4}$ and Chen and colleagues ${ }^{5}$ found a higher rate of preterm birth in First Nations women with diabetes than in their nonFirst Nations counterparts. Unlike Liu and colleagues, ${ }^{4}$ 


\begin{tabular}{|c|c|c|c|c|c|c|}
\hline \multirow[b]{2}{*}{ Outcome } & \multicolumn{3}{|c|}{ Other women } & \multicolumn{3}{|c|}{ First Nations women } \\
\hline & $\begin{array}{l}2002 / 03- \\
2005 / 06\end{array}$ & $\begin{array}{l}2006 / 07- \\
2009 / 10\end{array}$ & $\begin{array}{l}2010 / 11- \\
2014 / 15\end{array}$ & $\begin{array}{l}2002 / 03- \\
2005 / 06\end{array}$ & $\begin{array}{l}2006 / 07- \\
2009 / 10\end{array}$ & $\begin{array}{l}2010 / 11- \\
2014 / 15\end{array}$ \\
\hline \multicolumn{7}{|l|}{ Preterm delivery } \\
\hline $\begin{array}{l}\text { Rate per } 100 \text { births } \\
(95 \% \mathrm{Cl})\end{array}$ & $17.5(16.2-18.8)$ & $16.9(15.9-17.9)$ & $16.9(16.0-17.8)$ & $20.5(15.5-26.5)$ & $19.8(15.0-25.8)$ & $19.0(15.0-23.7)$ \\
\hline IRR $(95 \% \mathrm{CI})$ & & & & $1.17(0.90-1.54)$ & $1.18(0.90-1.54)$ & $1.12(0.89-1.41)$ \\
\hline $\begin{array}{l}p \text { for trend 2002/03- } \\
2014 / 15\end{array}$ & & 0.6 & & & 0.5 & \\
\hline \multicolumn{7}{|c|}{ Large for gestational age } \\
\hline $\begin{array}{l}\text { Rate per } 100 \text { births } \\
(95 \% \mathrm{Cl})\end{array}$ & $25.3(23.9-26.8)$ & $24.4(23.2-25.7)$ & $24.3(23.1-25.4)$ & $50.7(42.4-60.0)$ & $50.9(42.7-60.3)$ & $46.1(39.5-53.4)$ \\
\hline IRR $(95 \% \mathrm{Cl})$ & & & & $2.00(1.67-2.40)$ & $2.09(1.75-2.49)$ & $1.90(1.63-2.22)$ \\
\hline $\begin{array}{l}p \text { for trend } 2002 / 03- \\
2014 / 15\end{array}$ & & 0.006 & & & 0.3 & \\
\hline \multicolumn{7}{|l|}{ Congenital anomaly } \\
\hline $\begin{array}{l}\text { Rate per } 100 \text { births } \\
(95 \% \mathrm{Cl})\end{array}$ & $7.6(6.9-8.4)$ & $8.2(7.5-9.0)$ & $8.9(8.2-9.6)$ & $16.8(12.3-22.4)$ & $14.2(10.1-19.3)$ & $14.4(10.8-18.7)$ \\
\hline IRR $(95 \% \mathrm{Cl})$ & & & & 2.20 (1.62-2.99) & $1.73(1.25-2.39)$ & $1.62(1.23-2.13)$ \\
\hline $\begin{array}{l}p \text { for trend 2002/03- } \\
2014 / 15\end{array}$ & & 0.001 & & & 0.3 & \\
\hline \multicolumn{7}{|l|}{ Stillbirth } \\
\hline $\begin{array}{l}\text { Rate per } 100 \text { births } \\
(95 \% \mathrm{Cl})\end{array}$ & $1.4(1.1-1.8)$ & $1.3(1.1-1.7)$ & $1.2(1.0-1.5)$ & $3.1(1.4-5.8)$ & $5.1(2.9-8.4)$ & $1.1(0.4-2.6)$ \\
\hline IRR $(95 \% \mathrm{CI})$ & & & & $2.19(1.09-4.40)$ & $3.81(2.21-6.56)$ & $0.92(0.38-2.20)$ \\
\hline $\begin{array}{l}p \text { for trend 2002/03- } \\
2014 / 15\end{array}$ & & 0.5 & & & 0.2 & \\
\hline
\end{tabular}

we did not distinguish First Nations women living in or outside of First Nations communities; however, the majority of First Nations women in Ontario live outside of First Nations communities, ${ }^{24}$ which could explain the difference.

Like Oster and colleagues ${ }^{6}$ and Chen and colleagues, ${ }^{5}$ we found that babies of First Nations women were more likely than those of other women to be large for gestational age. However, we did not find differences in obstructed labour rates between the 2 cohorts, a finding that deserves further study. First Nations women with preexisting diabetes had a higher rate of babies with congenital anomalies than did other women with preexisting diabetes, a finding also reported by Oster and colleagues ${ }^{6}$ and Chen and colleagues. ${ }^{5}$ Moreover, First Nations women with gestational diabetes also had a higher rate of babies with congenital anomalies than their non-First
Nations counterparts. This suggests there may be a burden of undiagnosed type 2 diabetes among First Nations women classified as having gestational diabetes, which supports the need for greater screening for type 2 diabetes in First Nations women of reproductive age. The rate of stillbirth was higher among First Nations women than among other women, a finding also reported by other investigators. . $^{52-27}$

In the present study, about $85 \%$ of First Nations women consulted an obstetrician/gynecologist during their pregnancy, higher than the rate previously reported for on-reserve First Nations women in Ontario (64\%). ${ }^{4}$ As in the study by Liu and colleagues, ${ }^{4}$ the rate of visits to an internal medicine or endocrinology specialist was lower among First Nations women with gestational diabetes than among other women with preexisting diabetes. Only about $15 \%$ of women in both cohorts visited an 


\begin{tabular}{|c|c|c|c|c|c|c|}
\hline \multirow[b]{2}{*}{ Outcome } & \multicolumn{3}{|c|}{ Other women } & \multicolumn{3}{|c|}{ First Nations women } \\
\hline & 2002/03-2005/06 & $\begin{array}{c}2006 / 07- \\
2009 / 10\end{array}$ & $\begin{array}{l}2010 / 11- \\
2014 / 15\end{array}$ & $\begin{array}{l}2002 / 03- \\
2005 / 06\end{array}$ & $\begin{array}{c}2006 / 07- \\
2009 / 10\end{array}$ & $\begin{array}{l}2010 / 11- \\
2014 / 15\end{array}$ \\
\hline \multicolumn{7}{|l|}{ Preterm delivery } \\
\hline $\begin{array}{l}\text { Rate per } 100 \text { births } \\
(95 \% \mathrm{Cl})\end{array}$ & $12.1(11.5-12.6)$ & $12.1(11.6-12.5)$ & $11.8(11.4-12.3)$ & $11.9(9.0-15.5)$ & $11.8(8.9-15.3)$ & $14.4(11.8-17.3)$ \\
\hline $\operatorname{IRR}(95 \% \mathrm{Cl})$ & & & & $0.99(0.76-1.29)$ & $0.98(0.75-1.27)$ & $1.21(1.00-1.47)$ \\
\hline $\begin{array}{l}p \text { for trend } 2002 / 03- \\
2014 / 15\end{array}$ & & 0.6 & & & 0.1 & \\
\hline \multicolumn{7}{|c|}{ Large for gestational age } \\
\hline $\begin{array}{l}\text { Rate per } 100 \text { births } \\
(95 \% \mathrm{Cl})\end{array}$ & $16.3(15.6-17.0)$ & $15.0(14.4-15.6)$ & $14.0(13.5-14.5)$ & $49.4(43.2-56.3)$ & $50.1(43.9-56.9)$ & $45.9(41.2-51.1)$ \\
\hline $\operatorname{IRR}(95 \% \mathrm{CI})$ & & & & $3.03(2.65-3.48)$ & $3.34(2.92-3.82)$ & $3.27(2.93-3.66)$ \\
\hline $\begin{array}{l}p \text { for trend } 2002 / 03- \\
2014 / 15\end{array}$ & & $<0.001$ & & & 0.1 & \\
\hline \multicolumn{7}{|l|}{ Congenital anomaly } \\
\hline $\begin{array}{l}\text { Rate per } 100 \text { births } \\
(95 \% \mathrm{Cl})\end{array}$ & $5.7(5.3-6.1)$ & $5.3(5.0-5.6)$ & $6.0(5.7-6.3)$ & $8.0(5.7-11.0)$ & $5.4(3.5-8.0)$ & $8.0(6.2-10.3)$ \\
\hline $\operatorname{IRR}(95 \% \mathrm{CI})$ & & & & $1.40(1.02-1.93)$ & $1.03(0.70-1.53)$ & $1.34(1.04-1.72)$ \\
\hline $\begin{array}{l}p \text { for trend } 2002 / 03- \\
2014 / 15\end{array}$ & & $<0.001$ & & & 0.8 & \\
\hline \multicolumn{7}{|l|}{ Stillbirth } \\
\hline $\begin{array}{l}\text { Rate per } 100 \text { births } \\
(95 \% \mathrm{Cl})\end{array}$ & $0.5(0.4-0.6)$ & $0.5(0.4-0.7)$ & $0.4(0.3-0.5)$ & $1.1(0.4-2.5)$ & $1.6(0.7-3.2)$ & $1.0(0.4-2.1)$ \\
\hline $\operatorname{IRR}(95 \% \mathrm{Cl})$ & & & & $2.13(0.89-5.11)$ & $3.06(1.49-6.25)$ & $2.64(1.20-5.81)$ \\
\hline $\begin{array}{l}p \text { for trend 2002/03- } \\
2014 / 15\end{array}$ & & 0.005 & & & 0.3 & \\
\hline
\end{tabular}

ophthalmologist or optometrist during pregnancy, a low proportion considering current recommendations. ${ }^{28}$

Efforts to improve the quality of care and pregnancy outcomes in First Nations women with diabetes must acknowledge the agency of First Nations women and be grounded in an understanding of ongoing intergenerational impacts of colonization. $^{8-11}$

\section{Limitations}

First, women with preexisting diabetes may have been misclassified as having gestational diabetes owing to incomplete capture of such cases by the Ontario Diabetes Database. Second, the use of diagnostic codes to identify diabetes is likely to underestimate the number of cases in First Nations women if they are using health care resources at a lower rate, which may have biased our results toward the null. Third, some women, especially in northwestern
Ontario, may have received pregnancy care in Winnipeg, so their use of health care services would have been underestimated. Similarly, there has been no assessment of the completeness or quality of the Indian Register, with some First Nations people not identified in the register. Last, our analyses were age-standardized, but the lack of data on maternal prenatal exposures and risk factors (i.e., smoking, obesity, glucose levels) is a limitation that we acknowledge.

\section{Conclusion}

Our results confirm disparities in maternal and neonatal outcomes between First Nations women and other women in Ontario. Access to primary care for pregnant women over the study period seemed adequate; access to specialized care, especially for women with preexisting diabetes, needs to be improved. 


\begin{tabular}{|c|c|c|c|c|c|c|}
\hline \multirow[b]{2}{*}{ Service } & \multicolumn{3}{|c|}{ Other women } & \multicolumn{3}{|c|}{ First Nations women } \\
\hline & $\begin{array}{c}2002 / 03- \\
2005 / 06\end{array}$ & $\begin{array}{l}2006 / 07- \\
2009 / 10\end{array}$ & $\begin{array}{l}2010 / 11- \\
2014 / 15\end{array}$ & $\begin{array}{l}2002 / 03- \\
2005 / 06\end{array}$ & $\begin{array}{l}2006 / 07- \\
2009 / 10\end{array}$ & $\begin{array}{l}2010 / 11- \\
2014 / 15\end{array}$ \\
\hline \multicolumn{7}{|l|}{ Primary care } \\
\hline $\operatorname{IRR}(95 \% \mathrm{Cl})$ & & & & $0.94(0.91-0.97)$ & $0.92(0.89-0.94)$ & $0.88(0.86-0.90)$ \\
\hline $\begin{array}{l}p \text { for trend 2002/03- } \\
2014 / 15\end{array}$ & & $<0.001$ & & & $<0.001$ & \\
\hline \multicolumn{7}{|l|}{ Obstetrics/gynecology } \\
\hline $\begin{array}{l}p \text { for trend 2002/03- } \\
2014 / 15\end{array}$ & & $<0.001$ & & & 0.2 & \\
\hline
\end{tabular}

Table 3B: Use of health care services among First Nations women and other women in Ontario with preexisting diabetes, 2002/03 to $2014 / 15$

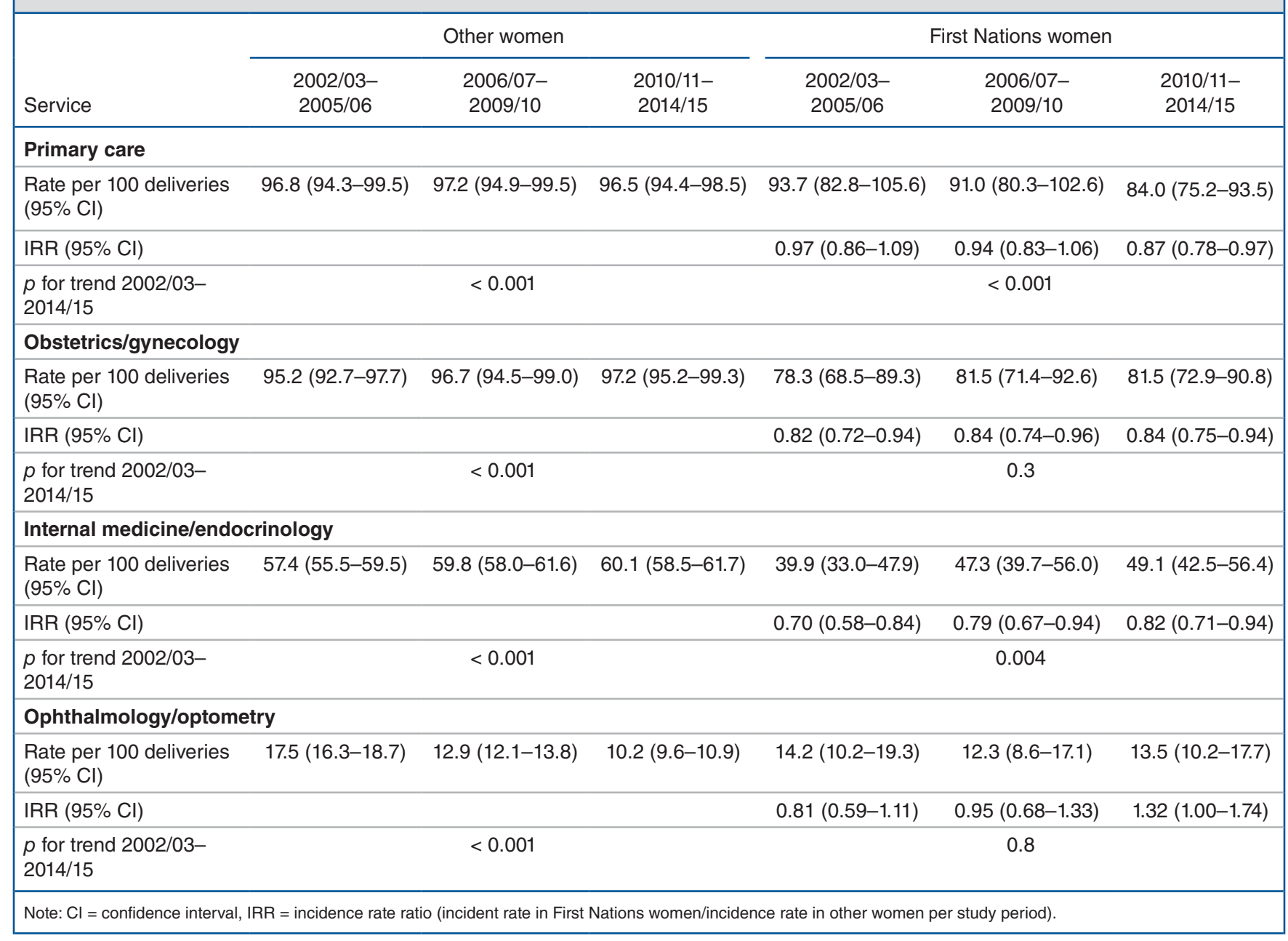




\begin{tabular}{|c|c|c|c|c|c|c|}
\hline \multirow[b]{2}{*}{ Service } & \multicolumn{3}{|c|}{ Other women } & \multicolumn{3}{|c|}{ First Nations women } \\
\hline & $\begin{array}{l}2002 / 03- \\
2005 / 06\end{array}$ & $\begin{array}{c}2006 / 07- \\
2009 / 10\end{array}$ & $\begin{array}{l}2010 / 11- \\
2014 / 15\end{array}$ & $\begin{array}{l}2002 / 03- \\
2005 / 06\end{array}$ & $\begin{array}{c}2006 / 07- \\
2009 / 10\end{array}$ & $\begin{array}{l}2010 / 11- \\
2014 / 15\end{array}$ \\
\hline \multicolumn{7}{|l|}{ Primary care } \\
\hline $\begin{array}{l}\text { Rate per } 100 \text { deliveries } \\
(95 \% \mathrm{Cl})\end{array}$ & $97.4(95.8-99.0)$ & $97.7(96.3-99.1)$ & $96.2(95.0-97.5)$ & $89.6(81.3-98.4)$ & $84.0(76.2-92.3)$ & $79.2(73.1-85.6)$ \\
\hline $\operatorname{IRR}(95 \% \mathrm{CI})$ & & & & $0.92(0.84-1.01)$ & $0.86(0.78-0.95)$ & $0.82(0.76-0.89)$ \\
\hline $\begin{array}{l}p \text { for trend 2002/03- } \\
2014 / 15\end{array}$ & & $<0.001$ & & & $<0.001$ & \\
\hline \multicolumn{7}{|l|}{ Obstetrics/gynecology } \\
\hline $\begin{array}{l}\text { Rate per } 100 \text { deliveries } \\
(95 \% \mathrm{Cl})\end{array}$ & $94.7(93.2-96.3)$ & $97.0(95.6-98.3)$ & $97.8(96.5-99.1)$ & $76.4(68.7-84.7)$ & $78.7(71.2-86.9)$ & $81.6(75.4-88.1)$ \\
\hline $\operatorname{IRR}(95 \% \mathrm{Cl})$ & & & & $0.81(0.73-0.89)$ & $0.81(0.74-0.90)$ & $0.83(0.77-0.90)$ \\
\hline $\begin{array}{l}p \text { for trend 2002/03- } \\
2014 / 15\end{array}$ & & $<0.001$ & & & 0.04 & \\
\hline \multicolumn{7}{|c|}{ Internal medicine/endocrinology } \\
\hline $\begin{array}{l}\text { Rate per } 100 \text { deliveries } \\
(95 \% \mathrm{Cl})\end{array}$ & $68.9(67.7-70.2)$ & $72.8(71.6-73.9)$ & $75.2(74.2-76.3)$ & $32.1(27.2-37.7)$ & $35.0(29.9-40.7)$ & $38.3(34.0-42.9)$ \\
\hline $\operatorname{IRR}(95 \% \mathrm{CI})$ & & & & $0.47(0.40-0.55)$ & $0.48(0.41-0.56)$ & $0.51(0.45-0.57)$ \\
\hline $\begin{array}{l}p \text { for trend 2002/03- } \\
2014 / 15\end{array}$ & & $<0.001$ & & & 0.02 & \\
\hline
\end{tabular}

\section{References}

1. Feig DS, Razzaq A, Sykora K, et al. Trends in deliveries, prenatal care, and obstetrical complications in women with pregestational diabetes: a populationbased study in Ontario, Canada, 1996-2001. Diabetes Care 2006;29:232-5.

2. Metcalfe A, Sabr Y, Hutcheon JA, et al. Trends in obstetric intervention and pregnancy outcomes of Canadian women with diabetes in pregnancy from 2004 to 2015. 7 Endocr Soc 2017;1:1540-9.

3. Aljohani N, Rempel BM, Ludwig S, et al. Gestational diabetes in Manitoba during a twenty-year period. Clin Invest Med 2008;31:E131-7.

4. Liu SL, Shah BR, Naqshbandi M, et al. Increased rates of adverse outcomes for gestational diabetes and pre-pregnancy diabetes in on-reserve First Nations women in Ontario, Canada. Diabet Med 2012;29:e180-3.

5. Chen L, Wang WJ, Auger N, et al. Diabetes in pregnancy in associations with perinatal and postneonatal mortality in First Nations and non-Indigenous populations in Quebec, Canada: population-based linked birth cohort study. BMF Open 2019;9:e25084.

6. Oster RT, King M, Morrish DW, et al. Diabetes in pregnancy among First Nations women in Alberta, Canada: a retrospective analysis. BMC Pregnancy Childbirth 2014;14:136.

7. Aboriginal peoples in Canada: First Nations people, Métis and Inuit - National Housebold Survey, 2011. Ottawa: Statistics Canada; 2013.

8. Honouring the truth, reconciling for the future: summary of the Final Report of the Truth and Reconciliation Commission of Canada. Winnipeg: Truth and Reconciliation Commission of Canada; 2015.

9. Reclaiming power and place: the final report of the National Inquiry into Missing and Murdered Indigenous Women and Girls. National Inquiry into Missing and Murdered Indigenous Women and Girls; 2019.

10. Allan B, Smylie J. First peoples, second class treatment: the role of racism in the health and well-being of Indigenous peoples in Canada. Toronto: Wellesley Institute; 2015.

11. Jacklin KM, Henderson RI, Green ME, et al. Health care experiences of Indigenous people living with type 2 diabetes in Canada. CMA7 2017;189:E106-12.

12. Understanding and improving Aboriginal maternal and child health in Canada: conversations about promising practices across Canada. Toronto: Health Council of Canada; 2011. Available: http://publications.gc.ca/collections/collection_2011/ ccs-hcc/H174-23-2011-eng.pdf (accessed 2019 July 11).
13. Oster RT, Mayan MJ, Toth EL. Diabetes in pregnancy among First Nations women. Qual Health Res 2014;24:1469-80.

14. Walker J, Lovett R, Kukutai T, et al. Indigenous health data and the path to healing. Lancet 2017;390:2022-3.

15. Walker JD, Rowe R, Jones CR. Describing the process of ethical conduct of research in an Ontario-wide First Nations diabetes research project. CMAJ 2018;190(Suppl):S19-20.

16. Slater M, Green ME, Shah B, et al. First Nations people with diabetes in Ontario: methods for a longitudinal population-based cohort study. CMAJ Open 2019;7:E680-8.

17. Ray JG, Urquia ML, Berger $\mathrm{H}$, et al. Maternal and neonatal separation and mortality associated with concurrent admissions to intensive care units. CMAF 2012;184:E956-62.

18. Booth GL, Luo J, Park AL, et al. Influence of environmental temperature on risk of gestational diabetes. CMA7 2017;189:E682-9.

19. Indian Act. R.S.C., 1985, c. I-5. Available: https://laws-lois.justice.gc.ca/eng/ acts/i-5/fulltext.html (accessed 2019 July 11).

20. Walker J, Pyper E, Jones CR, et al. Unlocking First Nations health information through data linkage. Int 7 Popul Data Sci 2018;3:8.

21. Perinatal health indicators for Canada. Ottawa: Public Health Agency of Canada; 2017.

22. Kramer MS, Platt RW, Wen SW, et al.; Fetal/Infant Health Study Group of the Canadian Perinatal Surveillance System. A new and improved populationbased Canadian reference for birth weight for gestational age. Pediatrics 2001;108:E35.

23. Berger H, Gagnon R, Sermer M, et al. Diabetes in pregnancy. F Obstet Gynaecol Can 2016;38:667-79.e1.

24. Aboriginal peoples in Canada in 2006: Inuit, Métis and First Nations, 2006 census. Aboriginal peoples. Ottawa: Statistics Canada; 2008. Cat no 97-558-XIE.

25. Macintosh MC, Fleming KM, Bailey JA, et al. Perinatal mortality and congenital anomalies in babies of women with type 1 or type 2 diabetes in England, Wales, and Northern Ireland: population based study. BMF 2006; 333:177.

26. Oster RT, Toth EL. A retrospective analysis of stillbirth epidemiology and risk factors among First Nations and non-First Nations pregnancies in Alberta from 2000 to 2009. 7 Obstet Gynaecol Can 2015;37:117-21. 
27. Auger N, Park AL, Zoungrana H, et al. Rates of stillbirth by gestational age and cause in Inuit and First Nations populations in Quebec. CMA7 2013;185: E256-62.

28. Wong TY, Sun J, Kawasaki R, et al. Guidelines on diabetic eye care: the International Council of Ophthalmology recommendations for screening, followup, referral, and treatment based on resource settings. Ophthalmology 2018;125: $1608-22$

Affiliations: Departments of Obstetrics and Gynaecology (Vélez) and Public Health Sciences (Vélez), Queen's University, Kingston, Ont.; ICES Central (Slater, Griffiths, Shah, Walker, Green), Toronto, Ont.; Department of Family Medicine (Slater, Green), Queen's University, Kingston, Ont.; Division of Endocrinology (Shah), Sunnybrook Health Sciences Centre; Department of Medicine (Shah), University of Toronto; Chiefs of Ontario (Sutherland, Jones), Toronto, Ont.; Memory Keepers Medical Discovery Team (Jacklin), Department of Family Medicine and Biobehavioral Health, University of Minnesota Medical School, Duluth, Minn.; School of Rural and Northern Health (Walker), Laurentian University, Sudbury, Ont.; Health Services and Policy Research Institute (Green), Queen's University, Kingston, Ont.

Contributors: Maria Vélez, Baiju Shah and Michael Green conceived the study. Maria Vélez, Baiju Shah, Roseanne Sutherland, Carmen Jones, Kristen Jacklin, Jennifer Walker and Michael Green designed the study. Rebecca Griffiths analyzed the data. Maria Vélez drafted the manuscript. All of the authors were involved in data interpretation, revised the manuscript critically for important intellectual content, approved the final version to be published and agreed to be accountable for all aspects of the work.
Funding: Funding was provided by the Ontario SPOR SUPPORT Unit, which is supported by the Canadian Institutes of Health Research (CIHR) and the Province of Ontario. Additional support was provided to Michael Green through the Brian Hennen Chair in Family Medicine, Queen's University, to Jennifer Walker through a Tier 2 Canada Research Chair in Indigenous Health and to Morgan Slater through a Health Systems Impact Fellowship from the CIHR. This study was supported by ICES, which is funded by an annual grant from the Ontario Ministry of Health and Long-Term Care.

Acknowledgements: The authors' partner in this project was the Chiefs of Ontario. The authors acknowledge the members of the project Patient Advisory Committee for providing insightful input. The authors also thank Katherine Lajkosz for her contribution to the statistical analysis.

Disclaimer: This study was supported by ICES, which is funded by an annual grant from the Ontario Ministry of Health and Long-Term Care (MOHLTC). The opinions, results and conclusions reported in this article are those of the authors and are independent from the funding sources. No endorsement by ICES or the Ontario MOHLTC is intended or should be inferred. Parts of this material are based on data provided by MOHLTC and the Canadian Institute of Health Information. Analyses and conclusions are solely those of the authors and do not reflect those of the data sources.

Supplemental information: For reviewer comments and the original submission of this manuscript, please see www.cmajopen.ca/content/8/1/ E214/suppl/DC1. 